\title{
Results of a tissue engineered pulmonary valve in humans assessed with CMR
}

\author{
Carsten Rickers*1, Andreas Entenmann ${ }^{1,2}$, Gunther Fischer ${ }^{1}$, Jens Scheewe ${ }^{1}$, \\ Michael Scheid ${ }^{1}$, Michael Jerosch-Herold ${ }^{3}$, Jan Braesen ${ }^{1}$, Inga Voges ${ }^{1}$, \\ Chris Hart ${ }^{1}$ and Hans-Heiner Kramer ${ }^{1}$
}

\author{
Address: ${ }^{1}$ University Hospital Schleswig-Holstein, Kiel, Germany, ${ }^{2}$ Universtiy Hospital Kiel, Kiel, Germany and ${ }^{3}$ Department of Radiology, \\ Brigham \& Women's Hospital \& Harvard Medical School, Boston, MA, USA \\ * Corresponding author
}

from 13th Annual SCMR Scientific Sessions

Phoenix, AZ, USA. 21-24 January 2010

Published: 21 January 2010

Journal of Cardiovascular Magnetic Resonance 2010, I 2(SuppI I):PI7 doi:I0.I 186/I532-429X-I2-SI-PI7

This abstract is available from: http://jcmr-online.com/content/I2/SI/PI7

(C) 2010 Rickers et al; licensee BioMed Central Ltd.

\section{Introduction}

Tissue-engineered (TEng) valves have recently been developed as an alternative to pulmonary valve replacement with homograft conduits to improve device life-time and function.

\section{Purpose}

To evaluate with advanced CMR techniques the morphological and functional properties of a decellularized porcine xenograft valve conduit (Matrix- ${ }^{\mathrm{rm}}$ ) and its successor product with additional equine pericardium sheathing (Matrix-P-Plus ${ }^{\mathrm{TM}}$; AutoTissue, Germany).

\section{Methods}

TEng valves had been implanted into the right ventricular outflow tract of 12 pts (age: $15 \pm 8,5$ yrs; Matrix- $P^{\mathrm{TM}} \mathrm{n}=7$; Matrix-P-Plus ${ }^{\mathrm{TM}} \mathrm{n}=5$ ) due to pulmonary stenosis or insufficiency within a median 5 months range (2-7 months) before a comprehensive follow-up by CMR. Echocardiography was suspicious of accelerated blood flow in the main pulmonary artery in 10 of those. The severity of the pulmonary valve stenosis was assessed by gradient echo cine MRI (FOV $270 \times 270 \mathrm{~mm}$, voxel size $1.88 \times 1.94 \times 5$ $\left.\mathrm{mm}, \mathrm{TR} / \mathrm{TE} / \alpha=4.4 \mathrm{~ms} / 2.7 \mathrm{~ms} / 15^{\circ}\right)$ and phase-contrast velocity mapping (FOV $270 \times 270 \mathrm{~mm}$, voxel size $1.64 \times$ $1.4 \times 7 \mathrm{~mm}, \mathrm{TR} / \mathrm{TE} / \alpha=15 \mathrm{~ms} / 2.5 \mathrm{~ms} / 30^{\circ}$, velocity encoding $($ VENC) $=400 \mathrm{~cm} / \mathrm{s}$ ) were applied. For tissue characterisation late enhancement imaging (Gd $0.1 \mathrm{mmol} / \mathrm{kg}$ ) using an ECG triggered 3D inversion recovery sequence $\left(\mathrm{TR} / \mathrm{TE} / \alpha=3.7 \mathrm{~ms} / 1.8 \mathrm{~ms} / 15^{\circ}\right.$; voxel size $1.17 \times 1.27 \times 10$ $\mathrm{mm}$ ) and T1 and T2 weighted turbo spin echo sequences were utilized.

\section{Results}

In 9 pts (33\%) CMR detected a significant conduit stenosis (Vmax $3.7 \pm 1,3 \mathrm{~m} / \mathrm{s}$ ) with mild or moderate insufficiency (RGF $21.3 \pm 5.9 \%$ ) post-surgery. In 3 pts the conduit was considered to be normal. In all pts with a stenosis, T1-weighted images showed significant paravalvular Gadolinium enhancement and wall thickening of the conduit. In 7 pts the "Matrix" valve conduit was replaced by a homograft. Explants were evaluated through histological analysis that showed granulomatous inflammation and increased fibrous tissue content correlating with CMR findings.

\section{Conclusion}

Conduit malfunction and paravalvular inflammation was successfully detected with CMR in pts post implantation of a decellularized pulmonary xenograft. As a consequence of the devastating short term results, use of these grafts was terminated at our center after initial use in 27 patients. 